УДК 338.486.3

JEL L26, L 83, L 84, Z32

DOI 10.31375/2226-1915-2020-1-115-126

О.Г. Пустовіт

ст. викладач кафедри

«Підприємництво та туризм»

pustovitt@ukr.net

ORCID ID: 0000-0001-5405-5558

С.В. Пустовіт

магістр спеціальності «Підприємництво, торгівля та біржова діяльність»

1111izaveta@gmail.com

ORCID ID: 0000-0003-3291-2904

Одеський національний морський університет Одеса, Украӥна

\section{ОСОБЛИВОСТІ БІЗНЕС-ПРОЦЕСІВ У ТУРИСТИЧНИХ КОМПАНІЯХ}

Анотація. У статті здійснено теоретичне осмислення особливостей формування та розвитку бізнес-прочесів у туристичних компаніях у сучасних умовах. Особливу увагу приділено обгрунтуванню сутності поняття "бізнес-прочес» як сукупності послідовних дій економічного, комериійного, бір-жового та підприємницького характеру, які зорієн-товані на отримання прибутку.

У роботі надана загальна характеристи ка бізнес-прочесу туристичного підприємства як взаємозалежна сукупність специфічних операчій, які трансформують вхідні ресурси у туристичну пропозицію для задоволення туристичного попиту потенційних клієнтів.

Проаналізувавши широкий перелік загальних властивостей бізнес-прочесу та трунтуючись на зазначених особливостях туристичної галузі, відокремлені основні сутнісні властивості бізнеспроцесу туристичної компанії, що характеризують ї̈ як набір взаємопов'язаних операцій, серед яких організаційність, взаємозалежність, безперервність, паралельність, дискретність.

Сформований перелік бізнес-процесів, притаманних туристичному підприємству, що відображають його особливості $i$ вирізняють $i_{3}$ сукупності підприємств іниих сфер.

Орієнтаиія на особливості бізнеспроцесів у туризмі в подальшому дозволить розробляти дієві механізми управління інтегрованими утвореннями на основі теоретичного та методологічного базису кониепиії розвитку суб'єктів господарювання.

Ключові слова: бізнес-прочес, сутність, властивості бізнес-прочесів, туристична компанія туристичний продукт.
УДК 338.486.3

JEL L26, L 83, L 84, Z32

DOI 10.31375/2226-1915-2020-1-115-126

Е.Г. Пустовит

ст. преподаватель кафедры «Предпринимательство и туризм» pustovitt@ukr.net ORCID ID: 0000-0001-5405-5558

Е.В. Пустовит

магистр кафедры «Предпринимательство, торговля и биржевая деятельность» 1111izaveta@gmail.com ORCID ID: 0000-0003-3291-2904

Одесский национальный морской университет, Одесса, Украина

\section{ОСОБЕННОСТИ БИЗНЕС-ПРОЦЕССОВ В ТУРИСТИЧЕСКИХ КОМПАНИЯХ}

Аннотация. В статье осуществлено теоретическое осмысление особенностей формирования и развития бизнес-процессов в туристических компаниях. Особое внимание уделено обоснованию сушности понятия «бизнес-прочесс» как совокупности последовательных действий экономического, коммерческого, биржевого и предпринимательского характера, ориентированные на получение прибыли.

В работе предоставлена общая характеристика бизнес-прочесса туристического предпри ятия как взаимосвязанная совокупность спеиифических операций, которая трансформирует входящие ресурсы для удовлетворения туристического спроса потенциальных клиентов.

Проанализировав иирокий перечень обиих свойств бизнес-прочесса и основываясь на указанных особенностях туристической отрасли, выделены основные сушностные свойства бизнеспроиесса туристической компании, характеризующчие ее как набор взаимосвязанных операций, среди которых организация, взаимозависимость, непрерывность, параллельность, дискретность.

Сформирован перечень бизнес-прочес сов, присущих туристической компании, который отражает его особенности и выделяет из совокупности предприятий других сфер.

Ориентация на особенности бизнес-проиессов в туризме в дальнейшем позволит разраба тывать действенные механизмы управления интегрированными образованиями на основе теоретического и методологического базиса концепщии развития субъектов хозяйствования.

Ключевые слова: бизнес-прочесс, сушность, свойства бизнес-прочессов, туристическая компания, туристический продукт.

(C) Пустовіт О.Г., Пустовіт Є.В., 2020 
UDC 338.486.3

JEL L26, L 83, L 84, Z32

DOI 10.31375/2226-1915-2020-1-115-126

\author{
O. Pustovit \\ senior lecturer of the department «Entrepreneurship and tourism» \\ pustovitt@ukr.net \\ ORCID ID: 0000-0001-5405-5558 \\ Ye. Pustovit \\ Master of the specialty «Entrepreneurship, trade and exchange activity» \\ 1111izaveta@gmail.com \\ ORCID ID: 0000-0003-3291-2904
}

Odessa National Maritime University, Odessa, Ukraine

\title{
FEATURES OF BUSINESS PROCESSES IN TOURIST COMPANIES
}

Abstract. There are preconditions for intensive tourism development in Ukraine, but they are clearly underused.

The expansion of political, economic, scientific and cultural ties with the countries of the world, the economic and political course of the country, a significant change in the outlook of its inhabitants have greatly contributed to the active development of the domestic tourism industry in the last decade. The problem of activating the potential of tourism industry development, ensuring sustainable tourism development and sustainability of the tourism industry, which requires the use of modern business modeling approaches, was significantly actualized.

The article gives a theoretical understanding of the peculiarities of the formation and development of business processes in tourism companies in modern conditions. Particular attention is paid to substantiating the essence of the concept of «business process», the general characteristic of the business process of the tourism enterprise as an interdependent set of specific operations.

After analyzing a wide list of common properties of the business process and based on these features of the tourism industry, the main essential features of the business process of the travel company are separated. The list of business processes inherent in the tourist enterprise, reflecting its peculiarities and differentiating it from the enterprises of other spheres, has been formed.

Considering the definition of the essence of the business process of the tourist enterprise and the separation of its properties, we can say that managing the business processes of a tourism enterprise is a managerial influence on the process of forming a tourist offer by implementing a set of techniques and measures that ensure the effective and rational functioning of business processes in order to fully meet the tourist demand.

Focusing on the features of business processes in tourism in the future will allow to develop effective mechanisms for managing integrated entities on the basis of theoretical and methodological basis of the development concept of economic entities.

Keywords: business process, essence, properties of business processes, tourist company, tourist product. 
Постановка проблеми. Важливість орієнтації підприємства на бізнес-процеси продиктована умовами часу. У сучасному економічному середовищі актуальності набуває не тільки налагодження бізнес-процесів як одного 3 напрямків роботи 3 внутрішнім середовищем, але і приведення їх у відповідність до швидкозмінних вимог зовнішнього середовища.

Сьогодні наукові підходи до визначення сутності дефініції, типології категорії бізнес-процесів, визначення їх ролі і взаємозв'язків не $\epsilon$ єдиними. Це ускладнює подальші дослідження в означеному напрямку. Тому проблема формування методології бізнес-процесами та досягнення практичних результатів $є$ актуальною і потребує ретельного дослідження.

В останні роки індустрія туризму зростає швидкими темпами. В умовах нестабільності зовнішнього середовища та жорсткої конкуренції серед вітчизняних туристичних підприємств все більш очевидним стає необхідність пошуку інноваційних методів управління. Розвиток туризму в сучасних умовах функціонування ринку послуг має певні особливості, які зумовлюють потребу у оновлених підходах до визначення бізнес-процесів, впровадження адекватних заходів в організації і веденні власної підприємницької діяльності в туристичних компаніях.

Управління бізнес-процесами в туристичних компаніях на сьогодні $\epsilon$ актуальною темою. Саме тому спостерігаємо зростання ролі використання та впровадження сучасних методів удосконалення бізнес-процесів.
Огляд останніх досліджень та літератури. Питанням щодо обгрунтування сутності бізнес-процесів, їх класифікації, методам удосконалення бізнес-процесів присвячена значна кількість наукових праць та економічних досліджень зарубіжних та вітчизняних науковців: Андерсена Б., Брімсона Д., Виноградової О., Горлачука В., Демінга Е., Друккера П., Єліферова В.Г., Зіндєра Є., Криворучко О., Масаловича О., Мельніченко С., Ойхмана $€$., Попова Е., Портера М., Рєпіна В., Робсона М., Тельнова Ю., Хаммера М., Харрінгтона Д., Чампі Д., Шеєра А., Уллаха $\Phi$. та інших. Їх наукові напрацювання $\epsilon$ великим кроком у розвитку науки про управління, дають змогу глибше зрозуміти сутність про-цесів, які відбуваються всередині ор-ганізації, систематизувати їx, розробити інструменти оцінювання ефективності та підвищити ефективність управлінської роботи.

Теоретико-методологічні основи до управління бізнес-процесами підприємств сфери послуг, зокрема туристичних підприємств, представлені у працях Бойко М., Босовської М., Гончар О., Євтушенко О., Есипової Е., Луцької Т., Мазаракі А., Мельника І., Мельниченко С., Михайліченко Г., Мізерної Г., Наливайко А., Пуліної Т., Сагалакової Н., Свірідової Н., Ткаченко Т., Тофа-нюка А., Шеєнкова К. та ін.

Сучасна економічна ситуація вимагає нових комплексних підходів та практичних рекомендацій щодо виявлення особливостей бізнес-процесів туристичної компанії та виявлення методів ефективного управління біз- 
нес-процесами туристичних підприємств.

Завдання дослідження. Метою статті є обгрунтування категорії «біз-нес-процес», виявлення особливостей формування бізнес-процесів у туристичних компаніях, дослідження пос-лідовності основних бізнеспроцесів туристичної компанії.

Основний матеріал дослідження. Діяльність будь-якого окремого туристичного підприємства $\epsilon$ сукупністю бізнес-процесів різного рівня. Проте формування понятійного апарату цієї проблематики для туристичної сфери вимагає дослідження сутності поняття «бізнес-процес».

Поняття «бізнес-процес» складається 3 двох термінів - бізнес та процес. Бізнес - це економічна, комерційна, біржова або підприєм-ницька діяльність, спрямована на отримання прибутку. Процес - послі-довна зміна станів або явищ, яка відбувається закономірно [1].

Поєднання понять «бізнес» та «процес» обумовило виникнення терміну i формує первинне значення сутності категорії «бізнес-процесів» як сукупності послідовних дій економічного, комерційного, біржового або підприємницького характеру, які зорієнтовані на отримання прибутку.

Існує багато визначень поняття бізнес-процесу, кожний з яких дає уявлення процесу з різних точок зору.

Б. Андерсен зазначає, що бізнес-процес - це ланцюг логічно взаємопов'язаних, повторюваних дій, у результаті яких використовуються ресурси підприємства для переробки об'єкта (фізично або віртуально) 3 метою досягнення певних вимірюваних результатів або продукції для задоволення внутрішніх або зовніш- ніх споживачів [2]. Таке розуміння бізнес-процесу базується на формальному відокремленні основних складників процесу, що включають такі поняття, як «вхід», «процес», «вихід», «управління», «постачальник процесу», «клієнт процесу».

В. Горлачук та I. Яненкова вважають, що бізнес-процес $є$ систематизованим, послідовним виконанням алогічно пов'язаних та взаємозалежних завдань із використанням ресурсів, що забезпечують виробничу діяльність, для створення продукції, яка має споживчі цінності для клієнта [3].

Інститут Еріксона визначає бізнес-процес як ланцюг алогічно пов'язаних, повторюваних дій, у результаті яких використовуються ресурси підприємства для переробки об'єкта (фізично чи віртуально) 3 метою досягнення певних вимірних результатів або продукції для задоволення внутрішніх і зовнішніх споживачів [4].

М. Хаммер та Дж. Чампі стверджують, що бізнес-процес має початок (вхід), певну кількість стадій діяльності і результат роботи, що отримується на виході. Вхід - це початок процесу, відповідно, вихід - це результат виконаної роботи [5].

Е. Демінг [6] визначає бізнеспроцеси компанії як джерело якості продукту та менеджменту, оскільки за рахунок ефективного розподілу ресурсів, орієнтації на раціональну, корисну роботу та відповідної процес-ної побудови компанії можуть повні-ше використовувати можливості 3 пошуку шляхів удосконалення цінності для клієнтів.

М. Хаммер визначає бізнеспроцес як сукупність різних видів ді- 
яльності, у межах якої «на вході» використовуються один або більше видів ресурсів, та в результаті цієї діяльності «на виході» створюється продукт, що має цінність для користувача [7].

Д. Харрінгтон стверджує, що бізнес-процес - це логічний, послідовний, взаємопов'язаний набір заходів. Він споживає ресурси, створюючи цінність для споживача [8].

У визначенні А. Масаловича [9] бізнес-процес - це потік дій (функцій), що мають цінність для клієнтів, які переходять від одного виконавця до іншого, а стосовно біль-ших бізнес-процесів - від одного структурного підрозділу до іншого.

Е. Зіндер [10] наголошує на тому, що бізнес-процес - це логічні серії взаємозалежних дій, які використовують ресурси підприємства для створення або одержання в доступному для огляду чи вимірному передбачуваному майбутньому корисного для замовника виходу, такого як продукт або послуга.

Найбільш широке визначення поняття бізнес-процесу, на нашу думку, запропоновано О. Виноградовою [1], яка характеризує його як циклічну сукупність взаємопов'язаних завдань (дій), що мають певні входи (необхідні ресурси) і виходи (результат), які є цінністю для споживача (внутрішнього або зовнішнього).

М. Портер [11] дає найбільш лаконічне визначення поняття бізнеспроцесу як сукупності різних видів діяльності, у межах якої на вході використовується один або більше видів ресурсів і в результаті цієї діяльності на виході створюється продукт, який має цінність для споживача.
На підставі цих визначень бізнес-процес розглядається в різних аспектах, але при цьому прослідковується переважна єдність у тлумаченні терміну, адже автори визначають його як послідовність дій, функцій, операцій, заходів для отримання результату.

Усі визначення об'єднує насамперед акцентування уваги на тому, що бізнес-процеси є безперервними, мають певні входи і виходи.

Отже, доходимо висновку, що в наукових колах поняття «бізнеспроцес» набуло більш-менш усталену дефініцію. Вже традиційним можна вважати технологічний підхід щодо його визначення, де ключовим $\epsilon$ акцент на комплексі дій (а не окремій операції), який за систематичного виконання генеруватиме результат, що має цінність для клієнта. Подібна дефініція передбачає також взаємозалежність і організаційну підпорядкованість дій, що зумовлює раціональність використання ресурсів й ефективність процесу.

Таким чином, ключовою ознакою бізнес-процесу визнається спрямованість на створення доданої цінності для клієнта (споживача) (рис. 1).

Основною метою діяльності туристичного підприємства, як туроператора, так і турагента, $є$ задоволення потреб споживачів у послугах туристичного, рекреаційного, екскурсійного (пізнавального) характеру, тому, на нашу думку, бізнес-процес туристичного підприємства - це взаємозалежна сукупність специфічних операцій (робіт), що трансформує вхідні ресурси у туристичну пропозицію для задоволення туристичного попиту. 


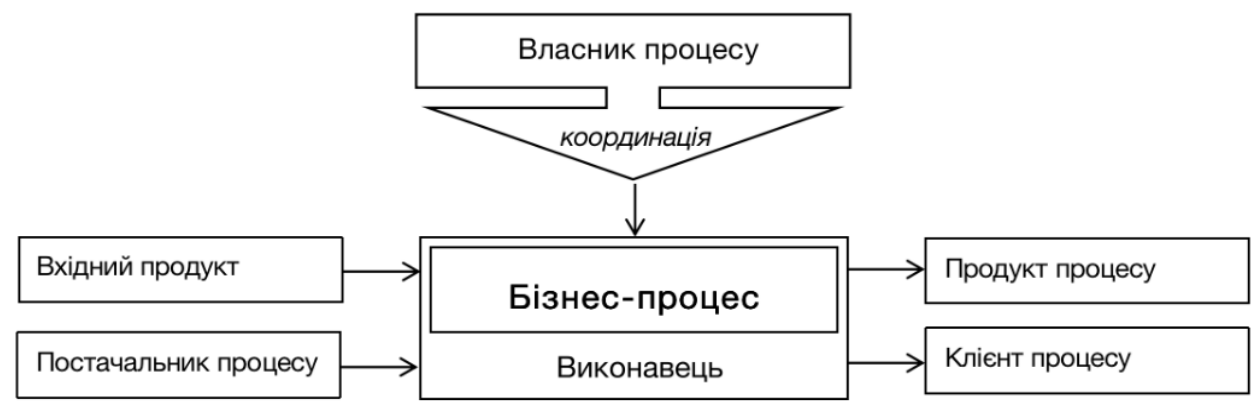

Рис. 1. Загальна характеристика бізнес-прочесу

Джерело: розробка авторів з використанням [1; 2; 6; 12; 13$]$

Сутність бізнес-процесу туристичного підприємства характеризується притаманними йому властивостями. Ці властивості розкривають природу бізнес-процесу саме туристичного підприємства, структурують розглянуті вище ключові ознаки.

Проаналізувавши широкий перелік загальних властивостей бізнес- процесу $[12 ; 13 ; 14 ; 15 ; 16]$, описаних у наукових літературних джерелах, та грунтуючись на зазначених особливостях туристичної галузі, можемо відокремити основні сутнісні властивості бізнес-процесу туристичної компанії, що характеризують іï як набір взаємопов'язаних операцій (рис. 2).

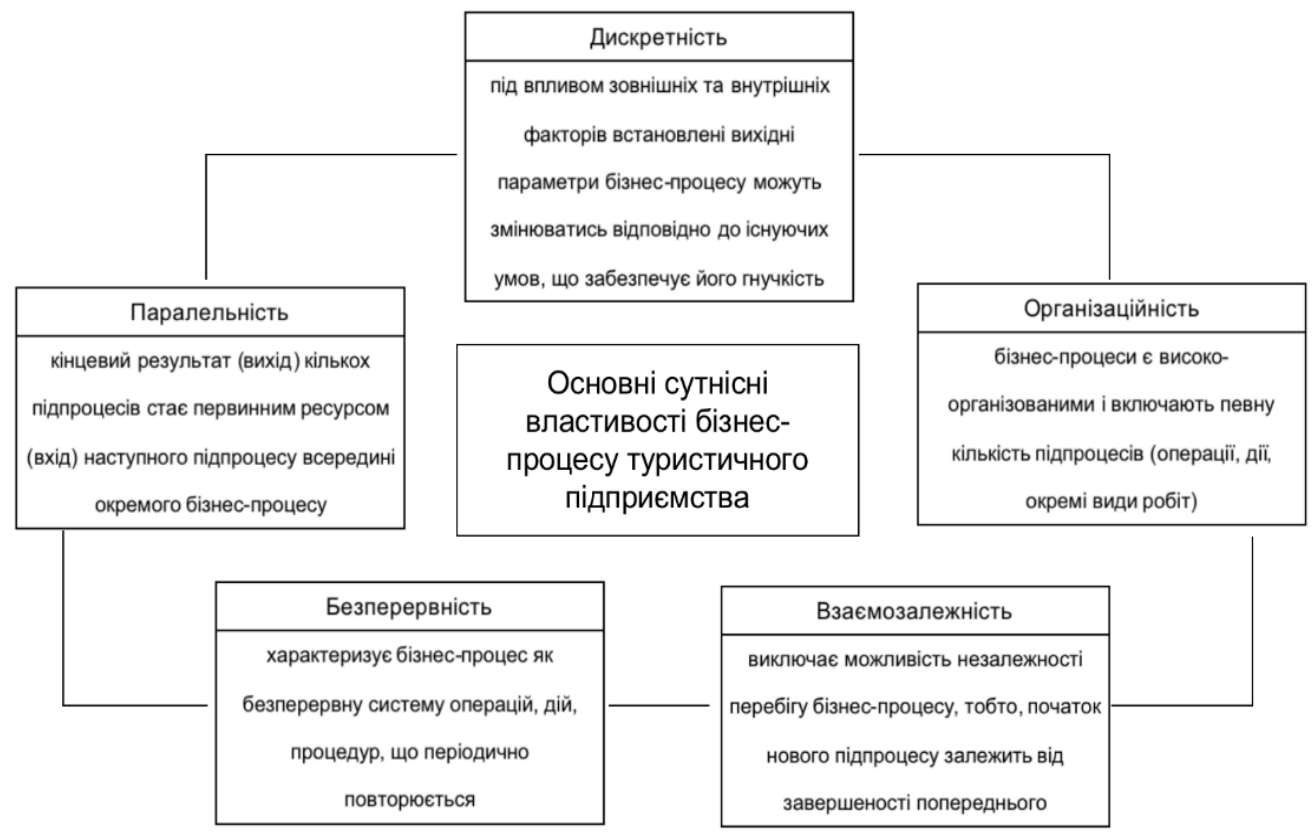

Рис.2. Основні сутнісні властивості бізнес-процесу туристичного підприсмства

Джерело: розробка авторів з використанням [14-16] 
Для виокремлення специфіки бізнес-процесів туристичного підприємства та специфічних рис управління ними слід розглянути особливості цього виду діяльності.
Розглянемо послідовність реалізації основних бізнес-процесів туристичних підприємств (рис. 3).

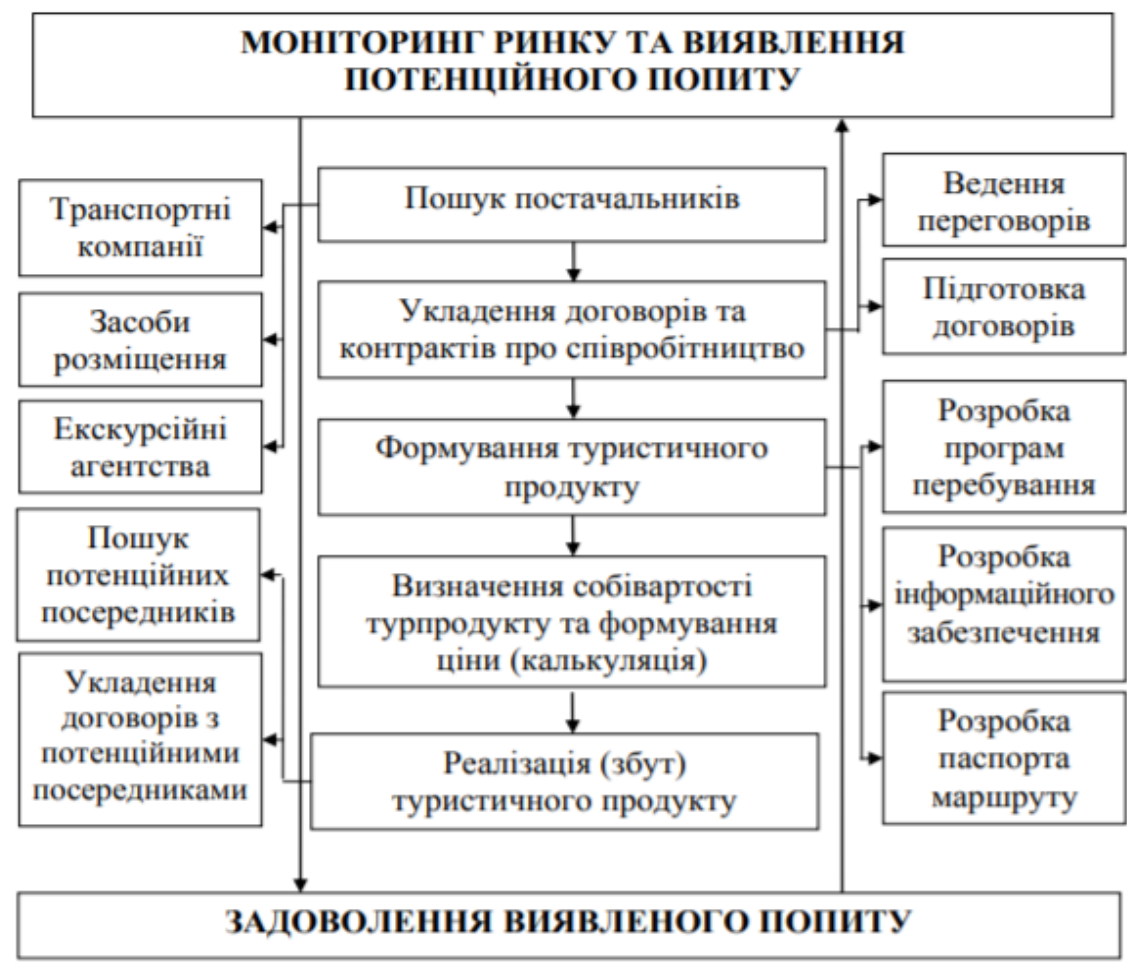

Рис. 3. Послідовність реалізаиії основних бізнес-процесів туристичного підприємства

Джерело: розробка авторів з використанням [12; 17$]$

Основні бізнес-процеси туристичного підприємства спрямовані на створення туристичного продукту.

Процес його проектування та підготовка до реалізації вимагає залучення значної кількості ресурсів (людських, матеріальних, фінансових, інформаційних тощо). Процес проектування туристичного продукту починається із моніторингу потреб споживачів і пошуку шляхів їх задо- волення. Проектування туристичного продукту охоплює значну кількість бізнес-процесів та підпроцесів всередині окремого бізнес-процесу. Переважна частина бізнес-процесів туристичного підприємства зосереджується на пошуку постачальників туристичних послуг (заклади розміщення, транспортні компанії) та процеси формування туристичного продукту (розробка турів). 
На підставі визначених особливостей реалізації бізнес-процесів туристичних підприємств можна сформувати перелік бізнес-процесів, притаманних туристичному підприємству, що відображають його особливості i вирізняють із сукупності підприємств інших сфер.
Схематично (рис. 4) наведено перелік основних бізнес-процесів туристичного підприємства; при цьому виокремлено тільки найважливіші, що забезпечують діяльність підприємства в цілому.

\begin{tabular}{|c|c|}
\hline 1. Розробка стратегіï & $\begin{array}{l}\text {-аналіз зовнішнь ого середовища } \\
\text {-визначення пріоритетів розвитку }\end{array}$ \\
\hline $\begin{array}{l}\text { 2. Аналіз ринку і потреб } \\
\text { споживачів }\end{array}$ & $\begin{array}{l}\text { •внзначення потреб споживачів } \\
\text { - дослідження ринку } \\
\text { •укладання договорів } 3 \text { постачальншкамп послуг }\end{array}$ \\
\hline $\begin{array}{l}\text { 3. Формування туристичного } \\
\text { продукту }\end{array}$ & $\begin{array}{l}\text {-формування туристичних напрямів } \\
\text {-визначення пакету послуг } \\
\text { - формування вартості туристичного продукту }\end{array}$ \\
\hline 4. Управління персоналом & $\begin{array}{l}\text {-підбір персоналу } \\
\text {-навчання пірсоналу } \\
\text {-розвиток персоналу }\end{array}$ \\
\hline $\begin{array}{l}\text { 5. Управління фінансової } \\
\text { діяльністю }\end{array}$ & $\begin{array}{l}\text {-управління фінансовимп ресурсамп } \\
\text {-ведення бухгалтерського обліку }\end{array}$ \\
\hline 6. Забезпечення ресурсами & $\begin{array}{l}\text {-планування ресурсів } \\
\text {-управління ресурсамп }\end{array}$ \\
\hline $\begin{array}{l}\text { 7. Контроль за ефективністю } \\
\text { діяльності }\end{array}$ & $\begin{array}{l}\text {-проведення внутрішшњ ого аудиту } \\
\text { •управління якістю туристичншх послуг }\end{array}$ \\
\hline
\end{tabular}

Рис. 4. Основні бізнес-прочеси туристичного підприємства

Джерело: розробка авторів з використанням [12; 16; 17$]$

У разі потреби перелік бізнеспроцесів може змінюватися, вони можуть вилучатися і додаватися залежно від специфіки діяльності та розмірів туристичного підприємства.

Специфічність бізнес-процесу, спрямованого на реалізацію туристичного продукту, проявляється у розмежуванні туристичних підприємств на туристичних операторів та туристичних агентів. Перші, у свою чергу, безпосередньо формують ту122 ристичний продукт та можуть самостійно його реалізовувати; туристичні агентства за специфікою своєї діяльності займаються лише збутом туристичних продуктів різних туристичних операторів за попередньо укладеними договорами.

Основні відмінності формування туристичного продукту для туристичних агентів зображені на рис. 5 . 


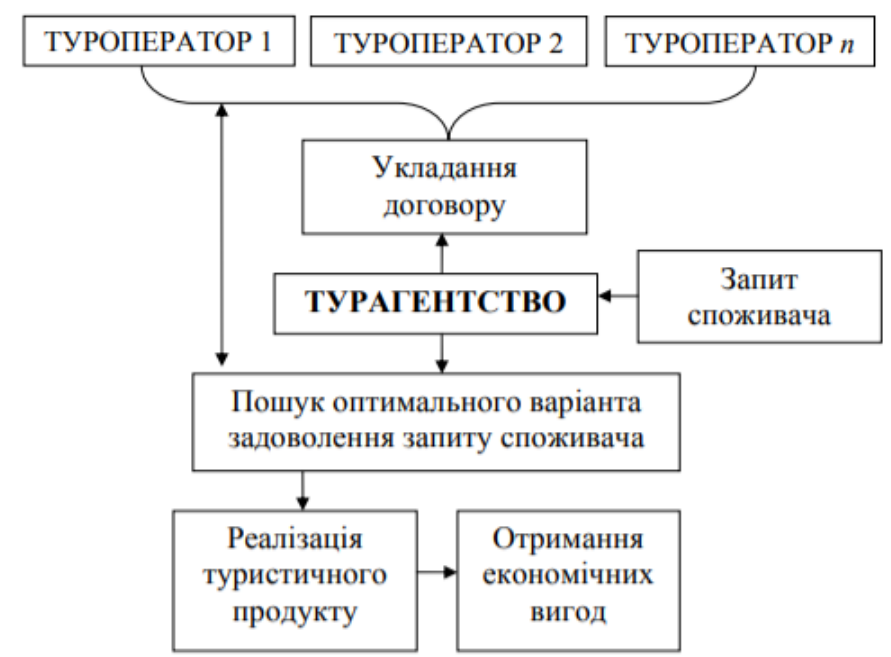

Рис. 5. Реалізаџія основних бізнес процесів туристичних агентств

\section{Джерело: розробка авторів з використанням [12]}

Туроператори є постачальниками туристичних продуктів для туристичних агентств, останні, у свою чергу, виконують роль посередника між туристичним оператором та потенційним споживачем туристичного продукту.

При цьому туристичне агентство $€$ повноцінним підприємством, що складається із взаємозалежної сукупності бізнес-процесів, які забезпечують злагоджену роботу цього типу підприємства.

Висновки. Теоретичне осмислення проблеми формування та розвитку бізнес-процесів у туризмі, що пов'язано із випереджаючим зростанням економіки на основі розвитку різних форм інтеграції суб'єктів господарювання, дозволило зробити висновок про відсутність наукових розробок, пов'яза-них із систематизацією особливостей бізнеспроцесів у туристичних компаніях.

3 метою удосконалення теорії розвитку бізнес-процесів у туристичних компаніях, приділено особливу увагу обгрунтуванню поняття «бізнес-процес», надано загальну характеристику бізнес-процесу туристичного підприємства.

Враховуючи визначення сутності бізнес-процесу туристичного підприємства та виокремлення його властивостей, можемо стверджувати, що управління бізнес-процесами туристичного підприємства - це управлінський влив на процес формування туристичної пропозиції шляхом реалізації сукупності прийомів та заходів, що забезпечують ефективне та раціональне функціонування біз-неспроцесів 3 метою повноцінного задоволення туристичного попиту. 


\section{СПИСОК ЛІТЕРАТУРИ}

1. Виноградова О.В. Реінжиніринг торговельних підприємств: теорія та методологія: дис. д-ра екон. наук: 08.06.01. Донецькк, 2006. 435 c.

2. Андерсен Б. Бизнес-прочессы. Инструменты совершенствования. М.: Стандарты и качество, 2003. 272 с.

3. Горлачук В.В. Економіка підприємства: Навчальний посібник. Миколаїв: Вид-во ЧДУ ім. Петра Могили, 2010. 344 c.

4. Ericsson Quality Institute. Business Process Management. Ericsson, Gothenburg Sweden, 1993. $170 \mathrm{p}$.

5. Хаммер М. Реінжинірінг корпораџии: Манифест революции в бизнесе. М.: Манн, Иванов и Фербер, 2006. 287 с.

6. Деминг Э. Выход из кризиса: Новая парадигма управления людьми, системами и прочессами. М.: Альпина Паблишер, 2012. 419 с.

7. Хаммер М. Реінжинірінг корпорации: Манифест революичи в бизнесе. М.: Манн, Иванов и Фербер, 2006. 287 с.

8. Харрингтон Д. Оптимизация бизнес-процессов: документирование, анализ, управление, оптимизация. СПб.: АЗБУКА БМикро, 2002. 314 с.

9. Масалович А. Повышение конкурентоспособности предприятий с помощью средств оперативно-стратегического управления. URL: http://www.marketing. spb.ru/conf/2002-12-ram/rozn_6.htm

10. Зиндер Е.3. Новое системное проектирование: информационные технологии и бизнес-реинжиниринг // Системы управления базами данных, 1996. № 1. C. 55-67.

11. Porter M. Competive Advantages: Creating and Sustaining Superior Performance. URL: https://www.albany.edu/ gs 149266/Porter\%20(1985)\%20-\%20 chapter\% 201. $p d f$

12. Мельниченко С.В. Управління бізнес-процесами в туризмі: монографія. К.: KHTEУ, 2015. $264 c$.

13. Ойхман Е.Г., Попов Э.В. Реинжиниринг бизнеса: реинжиниринг организации и информационные технологии. URL: http://refdb.ru/look/2076913.html

14. Репин В.В., Елиферов В.Г. Процессний подход к управлени. Моделирование бизнес-проиесов. М.: Манн, Иванов и Фербер, 2013. 544 c.

15. Гончар О.І. Мотиваційні засади розвитку конкурентного потенціалу підприємств туристичної сфери // Вісник Хмельницького університету. Х., 2010. № 3. C. 25-28.

16. Есипова Е.А. Конщепџия реинжиниринга бизнес-процессов в управлении туристическим предприятием // Современный научный вестник: Серия "Экономические науки», 2011. № 12(108). С. 13-22.

17. Сагалакова Н.О. Побудова мережі бізнес-прочесів туристичного підприємства. URL: http://www.ej.kherson.ua/journal/economic_15/3/28.pdf

18. Тофанюк. А. Бізнес-планування в туризмі: тенденції в сучасних умовах. URL: http://tourlib.net/statti_ukr/tofanjuk.htm

19. Батьковець Н.О., Кордек Е.І., Стецьюк Л.Р. Віртуалізація бізнес-прочесів через впровадження сучасних інформачійних технологій в туризмі. URL: http:// tourlib.net/statti_ukr/batkovec2.htm 


\section{REFERENCES}

1. Vinogradova, O.V. (2006). Reinzhiniring torgovelnih pidpriyemstv: teoriya ta metodologiya [Reengineering of trade enterprises: theory and methodology]: dis. Doctor of Economics. Sciences, Donetsk [in Ukrainian].

2. Andersen, B. (2003). Biznes-processy. Instrumenty sovershenstvovaniya [Business processes. Improvement tools], Moskva, 272 [in Russian].

3. Gorlachuk, V.V. (2010). Ekonomika pidpriyemstva: Navchalnij posibnik [Enterprise Economics: A Textbook], Mykolaiv, 344 [in Ukrainian].

4. Ericsson, G. (1993). Quality Institute. Business Process Management. Ericsson, Gothenburg Sweden.

5. Hammer, M. (2006). Reinzhiniring korporacii: Manifest revolyucii $v$ biznese [Corporate Reengineering: A Manifesto for Business Revolution]. Moskva, 287 [in Russian].

6. Deming, E. (2012). Vyhod iz krizisa: Novaya paradigma upravleniya lyudmi, sistemami $i$ processami [Getting Out of the Crisis: A New Paradigm for Managing People, Systems, and Processes]. Moskva, 419 [in Russian].

7. Hummer, M. (2006). Reinzhiniring korporacii: Manifest revolyucii v biznese [Corporate Reengineering: A Manifesto for Business Revolution]. Moskva, 287 [in Russian].

8. Harrington, D. (2002). Optimizaciya biznes-processov: dokumentirovanie, analiz, upravlenie, optimizaciya [Business Process Optimization: Documentation, Analysis, Management, Optimization]. St. Petersburg, 314 [in Russian].

9. Masalovich, A. (2002). Povyshenie konkurentosposobnosti predpriyatij s pomoshyu sredstv operativno-strategicheskogo upravleniya [Increasing the competitiveness of enterprises by means of operational and strategic management]. Retrieved from http://www.marketing.spb.ru/conf/2002-12-ram/rozn_6.htm [in Russian].

10. Zinder, E.Z. (1996). Novoe sistemnoe proektirovanie: informacionnye tehnologii $i$ biznes-reinzhiniring [New system design: information technologies and businessreengineering]. Database management systems, № 1, 55-67 [in Russian].

11. Porter, M. (2007). Competive Advantages: Creating and Sustaining Superior Performance [Competitive Advantages: Creating and Sustaining Superior Performance]. Retrieved from https://www.albany.edu/ gs149266/Porter\%20(1985)\%20\%20chapter\%201.pdf [in Ukrainian].

12. Melnichenko, S.V. (2015). Upravlinnya biznes-procesami v turizmi: monografiya [Management of business processes in tourism: a monograph]. Kiev, 264 [in Ukrainian].

13. Eichmann, E.G. \& Popov, E.V. (2017). Reinzhiniring biznesa: reinzhiniring organizacii $i$ informacionnye tehnologii [Business reengineering: organization re-engineering and information technology]. Retrieved from http://refdb.ru/look/ 2076913.html [in Ukrainian].

14. Repin, V.V. \& Eliferov, V.G. (2013). Processnij podhod k upravleni. Modelirovanie biznes-procesov [Process approach to management. Business Process Modeling]. Moskva, 544 [in Russian].

15. Gonchar, O.I. (2010). Motivacijni zasadi rozvitku konkurentnogo potencialu pidpriyemstv turistichnoyi sferi [Motivational principles of development of competitive potential of tourism enterprises]. Bulletin of Khmelnitsky University, Khmelnitsky, № 3. 25-28 [in Ukrainian]. 
16. Esipova, E.A. (2011). Koncepciya reinzhiniringa biznes-processov v upravlenii turisticheskim predpriyatiem [Business Process Reengineering Concept in Tourism Enterprise Management]. Sovremennyj nauchnyj vestnik: Seriya «Ekonomicheskie nauki», № 12(108), 13-22 [in Ukrainian].

17. Sagalakova, N.O. (2017). Pobudova merezhi biznes-procesiv turistichnogo pidpriyemstva [Building a business process network for a tourism enterprise]. Retrieved from http://www.ej.kherson.ua/journal/economic_15/3/28.pdf [in Ukrainian].

18. Tofaniuk, A. (2016). Biznes-planuvannya v turizmi: tendenciyi v suchasnih umovah [Business Planning in Tourism: Trends in Modern Conditions]. Retrieved from http://tourlib.net/statti_ukr/tofanjuk.htm [in Ukrainian].

19. Batkovets, N. \& Kordek, E. \& Stetsyuk, L. (2017). Virtualizaciya biznes-procesiv cherez vprovadzhennya suchasnih informacijnih tehnologij v turizmi [Virtualization of business processes through the introduction of modern information technologies in tourism]. Retrieved from http://tourlib.net/statti_eng/batkovec2.htm [in Ukrainian].

Стаття надійшла до редакиії 27.12.2019

Посилання на статтю: Пустовіт О.Г., Пустовіт Є.В. Особливості бізнес-процесів у туристичних компаніях // Розвиток методів управління та господарювання на транспорті: Зб. наук. праць, 2020. № 1 (70). C. 115-126. DOI 10.31375/2226-1915-2020-1-115-126.

Article received 27.12.2019

Reference a JournalArtic: Pustovit, O. \& Pustovit, Ye. (2020). Features of business processes in tourist companies. Development of management and entrepreneurship methods on transport, 1 (70), 115-126. DOI 10.31375/2226-1915-2020-1-115-126. 